УДК 621.313

\title{
УДОСКОНАЛЕННЯ МЕТОДІВ ТА ТЕХНІЧНИХ ЗАСОБІВ КЕРУВАННЯ СТРІЛКОВИМ ЕЛЕКТРОПРИВОДОМ ЗАЛІЗНИЧНОЇ АВТОМАТИКИ
}

Магістрант О.С. Івакін

\section{УСОВЕРШЕНСТВОВАНИЕ МЕТОДОВ И ТЕХНИЧЕСКИХ СРЕДСТВ УПРАВЛЕНИЯ СТРЕЛОЧНЫМ ЭЛЕКТРОПРИВОДОМ ЖЕЛЕЗНОДОРОЖНОЙ АВТОМАТИКИ}

\section{Магистрант А.С. Ивакин \\ IMPROVING METHODS AND ENGINEERING CONTROLS SWITCHES ELECTRIC RAILWAY AUTOMATION}

\section{Master student O.S. Ivakin}

Запропонований програмно-керований або адаптивний електропривод, дозволяє виключити в прочесі переводу вістряків стрілки ударні навантаження при виробиі технологічного зазору, щзо в свою чергу зменшує знос в кінематичній лінії (з'єднання тяг поступово розбиваються $i$ зазори збільшуються) стрілочного переводу та ліквідує негативний ефект - відбій вістряка від рамної рейки.

Ключові слова: стрілочний перевід, електропривод, адаптивна система, оптимальний режим, двигун, регулювання швидкості.

Предложенный программно-управляемый или адаптивный электропривод позволяет исключить в прочессе перевода остряков стрелки ударные нагрузки при выработке технологического зазора, что в свою очередь уменьшает износ в кинематической линии (соединение тяг постепенно разбиваются и зазоры увеличиваются) стрелочного перевода и ликвидирует отрицательный эффект - отбой остряка от рамного рельса.

Ключевые слова: стрелочный перевод, электропривод, адаптивная система, оптимальный режим, двигатель, регулировка скорости.

The proposed software-controlled or adaptive actuator eliminates in the transfer wits arrow shock in the development of the technological gap, which in turn reduces wear in the drive line (connection rods are gradually broken down and gap increases) switches and eliminates the negative effect - hang from the frame wits rail.

Keywords: railway switch, electric drive, adaptive system, optimal mode, motor, speed control.

\section{Вступ.}

Електроприводи отримали широке застосування в залізничній автоматиці та телемеханіки в якості базового засобу для механізації багатьох виробничих процесів. Стрілочний електропривод виконує функцію переміщення вістряків стрілочного переводу 3 одного положення в інше, замикання вістряків в крайньому положенні, отримання безперервного контролю фактичного положення стрілки [2]. Від його надійності і працездатності значною мірою залежить безперебійність і безпеку руху поїздів.
Експлуатаційно-технічні вимоги, а також різноманітність систем СЦБ зумовлює використання різних методів i технічних засобів керування стрілочним електроприводом.

Постановка проблеми у загальному вигляді та іï зв'язок із важливими науковими та практичними завданнями.

Постановка проблеми обумовлена існуючим станом проблеми керування стрілковим електроприводом у системи залізничного транспорту. На теперішній час застосовується релейна схема керування 3 
дуже обмеженими функціональними можливостями, як по керуванню, так і по контролю. Існує нагальна необхідність розширення іiі функціональних можливостей, особливо за функціями керування.

\section{Аналіз останніх досліджень i} публікацій.

Визначеній проблемі присвячена достатня кількість публікацій у фахових виданнях $[3,4,5,6,7]$. Зокрема у роботах $[1,2,6]$ сформульовані основні принципи побудови перспективного стрілкового електроприводу та алгоритмів його функціювання. У роботах $[3,4,5]$ визначені підходи до розроблення нової схеми керування стрілковим електроприводом 3 векторним керуванням. Окремі автори вказують на можливість застосування нейромереживного керування стрілковим електроприводом.

\section{Визначення мети та задачі дослідження.}

Метою роботи $\epsilon$ удосконалення методів та технічних засобів керування стрілковим електроприводом залізничної автоматики.

\section{Основна частина дослідження.}

Аналіз процесів, що протікають в системах електричної централізації і розгляд принципів їх побудови дозволяе вибрати оптимальний закон керування електроприводом. В [1] показано, що при оптимальному керуванні електроприводом процес переводу стрілки складається із двох інтервалів - розгону і гальмування. На обох стадіях швидкість електропривода повинна змінюватись по лінійному закону (рис.1). Повний цикл переводу вістряка стрілки визначається як Т. На інтервалі часу $0 \leq t \leq t_{1}$ швидкість приводу зростає від 0 до $V_{\max }-$ це стадія розгону. На інтервалі $t_{1} \leq t \leq T$ відбувається гальмування електроприводу.

Технічна реалізація оптимального закону керування може бути одержана за допомогою програмно-керованого або адаптивного електроприводу. Програмне управління припускає детерміноване завдання режимів переводу стрілки із метою досягнення поставленої цілі - одержання нульової швидкості на момент часу $T$. Але при складанні програми не можливо точно врахувати всі дестабілізуючи фактори, що відхиляють реальний процес руху стрілки від заданого.

Так, наприклад, неможливо повністю відтворити вплив на силу тяги переводу таких факторів:

- зміна під дією температури взаємодії вістряка із подушкою по якій він рухається;

- зносу поверхні тертя;

- наявність або відсутність мастил.

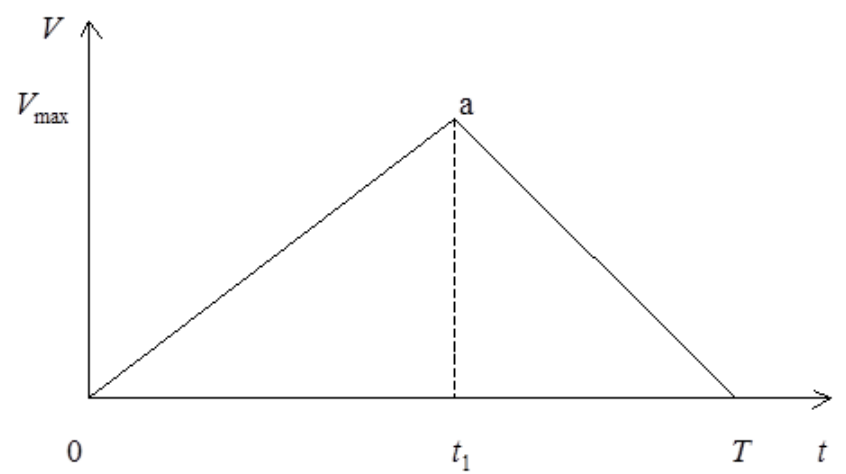

Рисунок 1 - Оптимальний закон регулювання швидкості електроприводу

Bce це приводить до того, що складена програма не завжди могла забезпечити необхідний режим роботи стрілочного приводу.

Адаптивна система автоматично здійснює вибір оптимального режиму переводу стрілки із одного положення в друге. На інтервалі розгону $0 \leq t \leq t_{1}$ швидкість (рисунок 2) змінюється по закону

$$
V_{p}(t)=a_{1} \cdot t
$$

де $a_{1}=$ const - прискорення розгону. 
В кінці інтервалу розгону швидкість приводу досягає максимальної величини, що $V_{p \max }=a_{1} \cdot t_{1}$ дорівнює

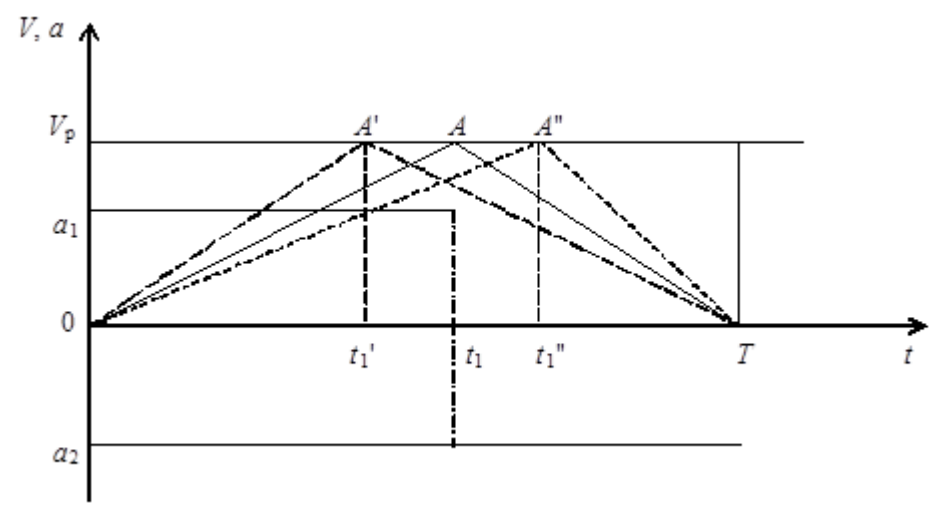

Рисунок 2 - Зміна швидкості руху вістряків стрілки в процесі переводу

Шлях, що пройшов вістряк стрілки на інтервалі розгону, визначається як

$$
S_{p \max }=V_{p \max } \cdot t_{1}=a_{1} \cdot t_{1}^{2} .
$$

На інтервалі гальмування $t_{1} \leq t \leq T$ швидкість руху вістряка стрілки зменшується по закону

$$
V_{2}(t)=V_{p \max }-a_{2}\left(t-t_{1}\right)
$$

де $a_{2}-$ прискорення гальмування.

Підставивши в (4) формулу одержуємо:

$$
V_{2}(t)=a_{1} \cdot t_{1}-a_{2}\left(t-t_{1}\right) \text {. }
$$

В кінці циклу переводу стрілки необхідно, щоб швидкість гальмування приводу зменшилась до нуля. Якщо вона зменшиться до нуля при $t<, T$ то вістряк стрілки не дійде до необхідного положення.

Якщо при $t>T$ швидкість відмінна від нуля, то буде спостерігатись удар вістряка по рамній рейці із подальшим "віджимом" вістряка.

Iз сказаного витікає, що умову оптимального переводу стрілки можна одержати прирівнявши формулу (5) до нуля при $t=T$

$$
a_{2}=a_{1} \frac{t_{1}}{T-t_{1}} .
$$

Момент часу $t_{1}$, що відповідає кінцю інтервалу розгону, визначимо із формули (3)

$$
t_{1}=\sqrt{\frac{S_{p \max }}{a_{1}}} .
$$

Залежність (6) може бути реалізована в керованому по швидкості електроприводу. Змінами величин прискорення на інтервалах розгону i гальмування в залежності від моменту часу початку гальмування, що позначені на рисунку 2 як $t_{1}^{\prime}, t_{1}, t_{1}{ }^{\prime \prime}$, досягається оптимальний перевід вістряка стрілки.

Із (6) і (7) витікає, що адаптивний електропривод в своєму складі повинен мати датчик, що фіксує момент закінчення інтервалу розгону.

Блок схема керування двигуном пропонованого електроприводу наведена на рисунку 3.

Для реалізації оптимального закону переводу вістряків стрілки імпульсні перетворювачі і двигун включені в систему автоматичного регулювання швидкості. Оптимізація динамічних характеристик регулювання швидкості переводу вістряків стрілки досягається застосуванням системи регулювання швидкості 3 підлеглим контуром регулювання струму двигуна. Контур регулювання струму в своєму складі має датчик струму ДС двигуна Д і регулятор РС. Контур регулювання швидкості включає в себе датчик швидкості ДШ і регулятор швидкості РШ.

Впровадження системи керування СК дозволило поліпшити експлуатаційні характеристики електропривода, а саме: 
забезпечити можливість регулювання

стрілки при використанні двигуна моменту та часу переводу стрілки, що значно поліпшує динамічні характеристики приводу постійного струму.

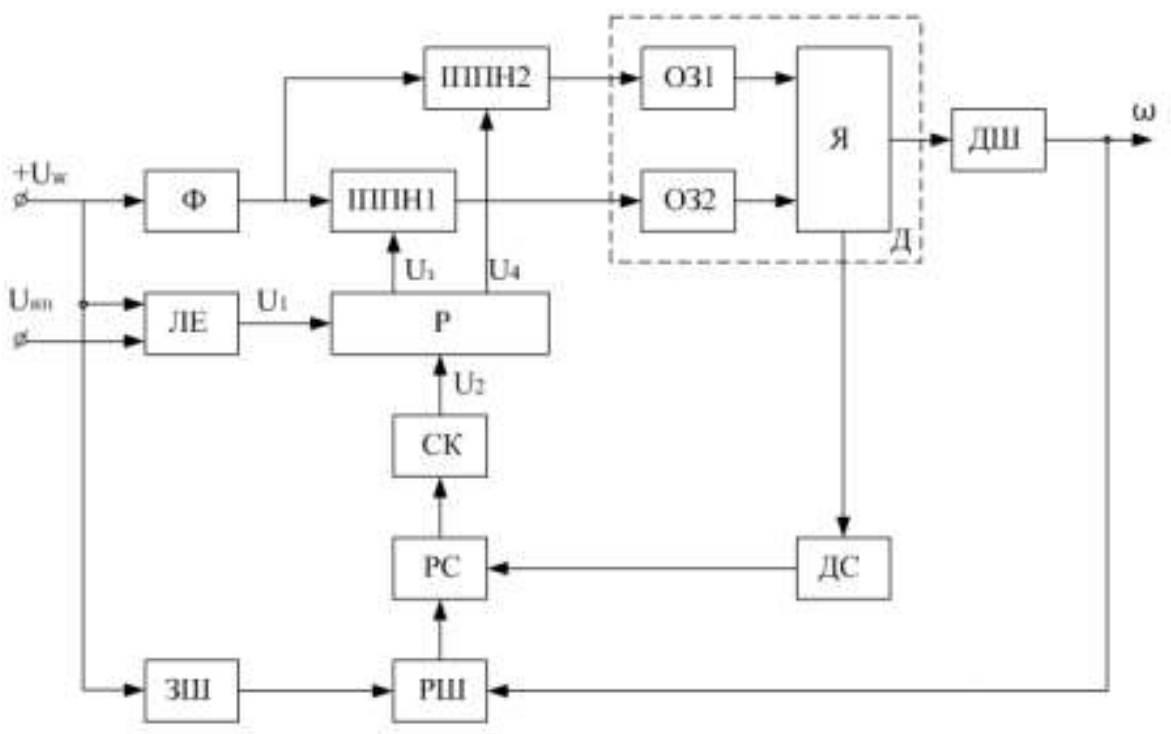

Рисунок 3 - Блок схема керування пропонованого електроприводу

Інтервали розгону та гальмування характеризуються плавним зростанням і зменшенням швидкості. Плавність розгону електричного двигуна виключає ударні навантаження, як у самому двигуні, так і у редукторі, що зменшує їх знос. Плавність зменшення швидкості електричного двигуна забезпечує безударний підвід вістряків до рамної рейки.

Висновки 3 дослідження i перспективи, подальший розвиток у даному напрямку
На теперішній час в промисловості мають широке розповсюдження частотні перетворювачі зі скалярним та векторним керуванням. Для залізничних доріг актуальні обидва випадки: пристрої зі скалярним керуванням та відносно неглибоким діапазоном регулювання швидкості можуть використовуватися на бокових, другорядних та інших станційних колій, а високо динамічні приводи 3 векторним керуванням будуть доцільні на головних коліях та сортувальних гірках.

\section{Список використаних джерел}

1. Мойсеєнко В.І., Щербак К.Я. Синтез алгоритму адаптивного управління електроприводом стрілочного переводу . Інформаційно-керуючі системи на залізничному транспорті №4,2004. - С. 31-34.

2. Резников Ю.М. Электроприводы железнодорожной автоматики и телемеханики.М.: Транспорт, 1985.-287c.

3. Буряковский С.Г., Обруч И.В., Смирнов В.В. Разработка скалярного и нейросетевого управления стрелочным переводом / Сб. XVII междунар. научн.-техн. конф. "Проблемы автоматизированного электропривода " // Харьков: НТУ ХПИ, 2010. —C.574576.

4. Буряковський С.Г., Смірнов В. В., Мойсеєнко В.І., Семчук Р.В., Демченко Ф.О. Застосування керованого частотного електропривода в стрілочному переводі / Збірник XVII міжнар. Наук.-техн. конф. "Інформаційно-керуючі системи на залізничному транспорті" // Харків: Укрдазт, 2009. - №4.- С. 105-108. 
5. Акімов Л.В., Буряковський С.Г., Маслій А.С., Смірнов В.В. Поліпшення динаміки залізничного стрілкового переводу 3 частотно-керованим електроприводом при нестаціонарних режимах роботи // Электротехнические и компьютерные системы № 05(81), 2012, c. 22-30.

6. Кондратенко С.Л. Перспективный стрелочный переводный комплекс. Каким ему быть? //Автоматика, связь, информатика.// №10, 2010, - c.5-7.

7. Буряковский С.Г. Системы скалярного и нейросетевого управления электроприводом стрелочного перевода [Текст] / Буряковский С.Г., Обруч И.В., Смирнов В.В. // Сборник научных трудов "Вестник НТУ "ХПИ" : Проблеми автоматизованого електроприводу. Теорія і практика. №28 - Вестник НТУ "ХПИ", 2010. - ISSN 2079-8024

Рецензент д-р техн. наук, професор Моісєєнко В.I.

Івакін Олександр Сергійович магістр, Автоматика та комп 'ютерні системи управління рухом поӥздів Українська державна академія залізничного транспорту. Tел.: (067) 260-96-41. E-mail: sahaivakin@mail.ru

Ivakin Oleksandr Serhiyovych master, Automation and computer train control system Ukraine State Academy of Railway Transport.Tel.: (067) 260-96-41.E-mail: sahaivakin@mail.ru 